\title{
Evidence for artificial magnetite coating on Iberian armoury $\left(^{(\cdot)}\right.$
}

\author{
L. García*, A. Javier Criado*, Antonio J. Criado*, J. Chamón*, F. Penco*, J. Alonso***, R. Arévalo****, \\ J.A. Martínez* and C. Dietz**
}

Abstract

A metallographic study of two pre-roman Iberian arms, affected by a cremation process, revealed the presence of
an outer magnetite layer, providing highly protective properties. This layer is extraordinarily tenacious and of very
homogeneous thickness, indicating an intentional manufacturing process rather than an accidental formation
during the severe heating/cooling cycles the artefact suffered. Up to date, the intentional production of these types
of layers has been attributed to a welding process of three different metallic sheets, here an alternative model is
proposed, allowing, as could be simulated in the laboratory, the virtually exclusive formation of a magnetite
coating.

Keywords

Iberian armoury; Early iron; SEM; Falcate; Artificial magnetite layer; Archaeometallurgy.

\section{Evidencias de un recubrimiento de magnetita artificial en el armamento íbero}

Resumen

Palabras clave

\begin{abstract}
Se presenta un estudio metalográficos de dos armas prerromanas afectadas por un proceso de cremación. Las armas poseen un recubrimiento exterior de magnetita que las confieren unas altas propiedades de protección frente a la corrosión. Esta capa es extraordinariamente tenaz y posee un espesor muy homogéneo, indicando que son producto de un proceso de fabricación intencionado más que una formación accidental durante los varios ciclos de calentamiento/enfriamiento que han sufrido los objetos. Hasta la fecha, la producción intencional de este tipo de recubrimientos ha sido atribuida a un proceso de soldadura de tres láminas metálicas diferentes. En este trabajo se propone un modelo alternativo de formación, el cual permite una simulación en el laboratorio en la que se forma exclusivamente una capa de magnetita.
\end{abstract}

Armamento ibérico; Edad del hierro; MEB; Falcate; Capa de magnetita artificial; Arqueometalurgia.

\section{INTRODUCTION}

The Iberian culture basically covered the eastern and southern coasts of the Iberian Peninsula, in between the $5^{\text {th }}$ and $1^{\text {st }}$ century B.C., reaching as northern limit the river Herault in France ${ }^{[1}$ y 2$]$. The term "iberians" is thus associated with people living during Iron Age II in Andalusia and the Mediterranean coastal zone of Spain. The origin of their name is possibly due to the river Iber or Iberus, today identified as Ebro, though first historical reference to the Iberians settling at the coast of Huelva were already made be Greek colonists. Intense trading contacts with the
Phoenicians, Greeks, and Carthaginians could be verified. Finally, when the Roman Republic subsequently conquered the Iberian Peninsula, they nearly completely absorbed the local culture and languages of the Iberian communities.

These tribes practised nearly exclusively cremation burials, where the body was burned together with personal belongings such as weapons or endowment objects. Consequently, in a warriors grave from an Iberian necropolis, it is frequent to discover, remains of the incinerated body and objects used by the individual in life. The most characteristic Iberian weapons were defensive arms like shields, greaves

\footnotetext{
(•) Trabajo recibido el día 2 de Julio de 2009 y aceptado en su forma final el día 11 de Agosto de 2010.

* Dpt. of Material Science and Metallurgic Engineering, Faculty of Chemistry, Complutense University of Madrid, Spain.

** Centre for Archaeometry and Archaeological Analysis (C.A.I. AAA), Faculty of History and Geography, U.C.M., 28040 Madrid (Spain).

${ }^{* * *}$ Archaeologist of the Diputación Foral de Álava, Museum of Armoury of Álava, Spain.

**** School of Engineering and Materials Science, Queen Mary, University of London, UK.
} 
or helmets combined with offensive ones such as falcatas, lances, and different types of javelins, as pilum or soliferreum ${ }^{[3-5]}$.

These weapons were recognised and documented by the roman armies as quite sophisticated and powerful due to its elevated steel quality and properties $^{[6-11]}$ during the conquest of the Iberian Peninsula, in turn causing reinforcement of the standard equipment of roman legions.

For manufacturing of the steel, raw steel plates were buried up to three years where weakened parts of the metal corroded, the remains were used for forging of the falcata. The blade was usually then made of three laminas of the obtained material in a bloomery, which is a furnace operated at low temperature where carbon monoxide resulting from incomplete combustion of charcoal reduces iron oxides to metallic iron without melting the material. The material was forged above its recrystallization temperature, followed by a normalised cooling at air. In case the blade used fullers, these were also hot forged. When inlets were foreseen, engraving was carried out at room temperature using a burin, the relieves were after completion of the workpiece filled with precious metals, silver, gold or bronze. Finally, the artificial magnetite layer was created ${ }^{[12-18]}$.

On many of those weapons recovered from archaeological sites up to date, a superficial magnetite layer can be distinguished ${ }^{[19-23]}$. As this oxide layer provides excellent anticorrosive properties, many iron specimens have remained in excellent conditions of conservation. Whether these layers were produced intentionally on a large scale is currently topic of scientific discussions, but relatively few references can be found in the specialised literature. This may be partly due to that, during classical interventions of excavation and restoration, these layers were often mistaken as natural oxide formed by habitual corrosion processes in irons of archaeological origin. An incorrect interpretation of the presence of magnetite thus not only affects the perception we have regarding early Iberian metallurgy, but also compromises the intervention strategy to be chosen for restoration and conservation of such artefacts. Taking into account the quantity of similar archaeological findings belonging to the pre-roman period of the Iberian Peninsula, it seems quite likely that most of Iberian and Celt Iberian arms may have once been coated with a black magnetite patina ${ }^{[24]}$, upon which often inlay work was carried out in silver. Generally, these type of weapons are found in necropolis, but numerous artefacts were also recovered from a different archaeological context. Those presenting a worse degree of conservation are usually suffered cremation processes and were later on buried in a geochemically aggressive environment.

In the present work the metallographic investigation on two typical Iberian arms is presented, a falcata from the Museum of Armory in Álava, Spain, (Fig. 1) and a pilum from the Copper Museum in Cerro Muriano, Córdoba, Spain, (Fig. 2).

Both have, though in different grades of conservation, the presence of a magnetite layer of faint black colour. The chronology of the samples oscillates between the $5^{\text {th }}$ and $2^{\text {nd }}$ century B.C.

Up to date, the intentional production of these types of layers has been attributed to a welding process of three different metallic sheets ${ }^{[24]}$, here an alternative model is proposed. The objective is to contribute to the development of an adequate

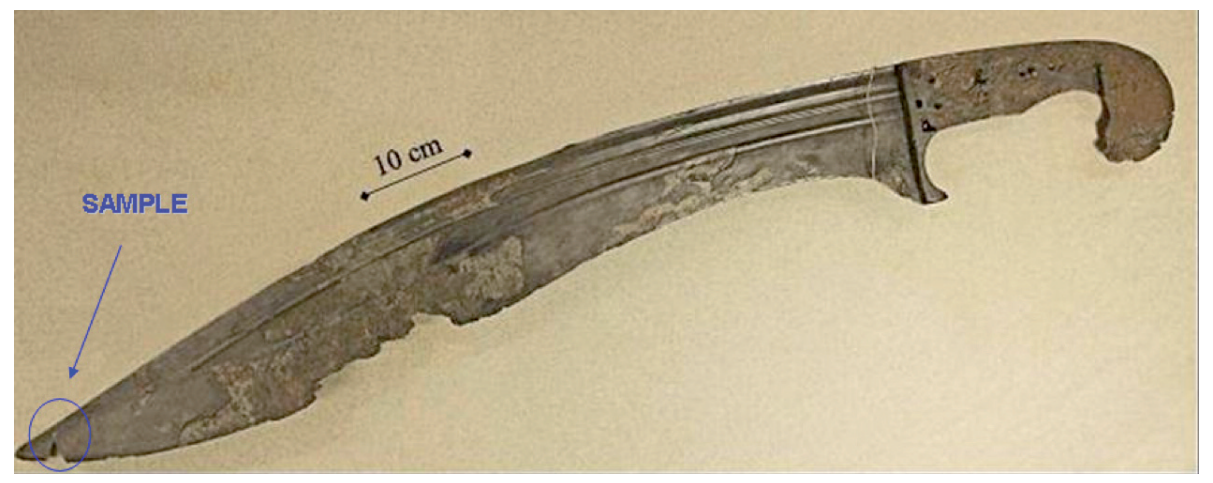

Figure 1. Iberian falcate, belonging to the collection of the Museum of Armory in Vitoria, Álava. The site where the sample was extracted is highlighted.

Figura 1. Falcata ibérica, perteneciente a la colección del Museo de la armería de Vitoria, Álava. Se señala en la imagen el lugar donde se ha extraído la muestra. 


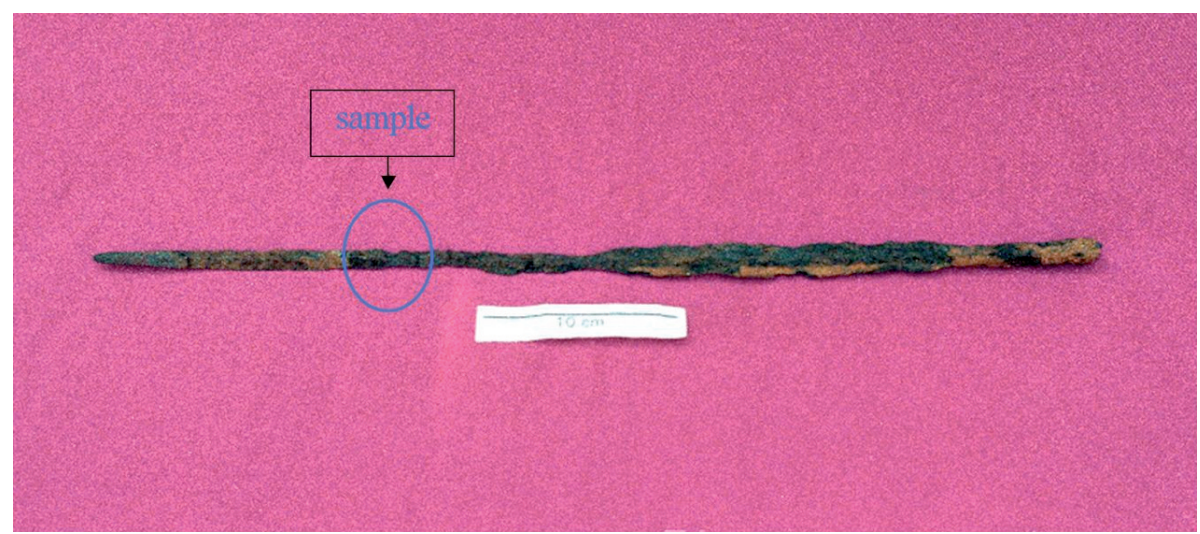

Figure 2. Iberian Pilum, Copper Museum in Cerro Muriano (Córdoba, Spain). The site where the sample was extracted is highlighted.

\section{Figura 2. Pilum ibérico, depositado en el Museo del Cobre de Cerro Muriano (Córdoba, España). Se señala en la imagen el lugar donde se ha extraído la muestra.}

methodology for characterisation of the morphology of natural and artificial magnetite layers and to investigate which procedures and techniques could have been applied by Iberian craftsman in order to obtain this type of surface protection. The techniques employed for this purpose were Scanning Electron Microscopy (SEM), conventional optical microscopy and Electron Probe Micro Analysis (EPMA). Subsequently, the production process was simulated under slightly oxidising conditions with the aim to obtain a uniform, tenacious and adherent magnetite layer similar to those present on the archaeological samples.

\section{EXPERIMENTAL}

The studied samples were taken from different, representative zones distributed over the weapons under investigation (Figs. 1 and 2). With the pillum it would have been necessary to sample at the tip, the only zone where the magnetite layer was still unaltered, but this would have caused irreversible damage to this valuable archaeological sample and had to be therefore discarded. For metallographic observation they were embedded in polyester resin and conventionally grinded and polished (from $\alpha$ $(0.3 \mu \mathrm{m})$ to $\gamma(0.03 \mu \mathrm{m}$, Buehler $)$. The sample surface was then etched with a $4 \%(\mathrm{~m} / \mathrm{V})$ ethanolic solution of nitric acid for $15 \mathrm{~s}$. For examination of the metallic structure using SEM, the ancient steel samples were additionally gold sputtered because they were embedded in resin. The SEM was coupled with an Energy Dispersive X-ray (EDX) detector, providing additional information on chemical composition. For EPMA analysis the embedded specimen were used without sputtering.

In order to prove the viability of an intentional formation of a protective magnetite layer, a laboratory simulation of this process was carried out. Boronoxide $\left(\mathrm{B}_{2} \mathrm{O}_{3}\right)$ was used as fluxard, applying furnace temperatures between 800 and $1100^{\circ} \mathrm{C}$ at different times. For the study of iron oxide formation (wüstite, hematite, magnetite), a steel likewise to those available during pre-roman times in the Iberian Peninsula has been used, in particular a DIN 17210 material with a carbon content (mass percentage) ranging from $0.12 \%$ to $0.18 \%$.

\section{RESULTS AND DISCUSSION}

Macroscopic surface observation by optical and scanning electron microscopy proves that both Iberian samples, the falcata and the pilum, were covered by a magnetite layer. In the first case, this magnetite layer can be easily distinguished and remains almost intact over the whole surface of the original item (Figs. 3, 4 y 6), in the second, this layer survived intact only in the zone round the spearhead. Possibly the cremation temperatures were considerably different and in the case of the pilum were that high, that most of the artificial surface layer was braking off, with exception of a zone close to the top point.

The magnetite layer was attributed to an intentional creation rather than to the presence of an evolution surface corrosion consisting in arbitrary 


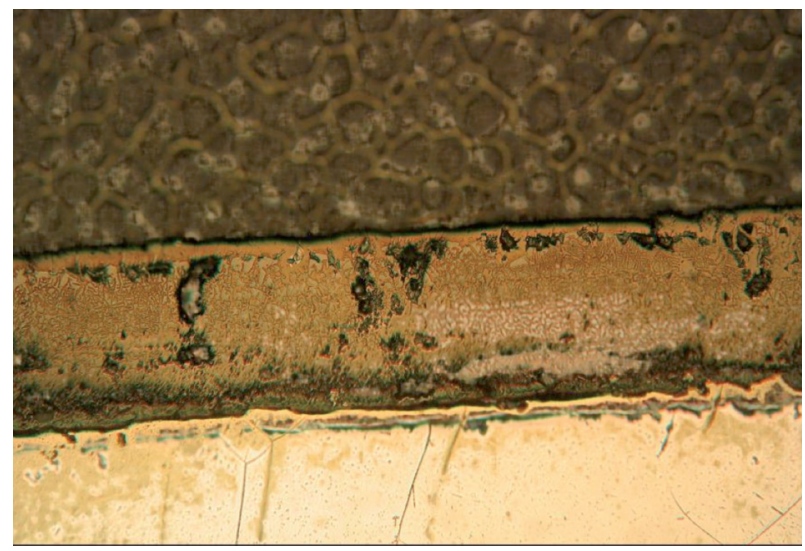

Figure 3. Detail of the artificial magnetite layer of the Iberian falcata, obtained by optical microscopy.

Figura 3. Detalle de la capa de magnetita artificial de la falcata ibérica. Imagen obtenida por microscopía óptica.

changes in morphology and composition caused by physical-chemical variations of the surrounding soil. Artificial magnetite layers show strong adherence and impermeability against compounds of atmospheric or geochemical origin, further they possess a tenacity nearly equal to that of the base steel. These properties provide a notable protection against corrosion, including during long term burial. The presence of these type of coatings in archaeological findings may be further characterised by:

- A black or dark gray colour with bluish shade. It can be finished in matt colour by polishing, acquiring an intense brilliancy with metallic tint.

- Composed by a very homogeneous magnetite $\left(\mathrm{Fe}_{3} \mathrm{O}_{4}\right)$ layer, though other iron oxides directly superposed on the basis steel may be detected. These are result of electrochemical corrosion due to penetration of electrolytes present in the surrounding soil in which the item was buried, because the outer layer, though providing efficient protection, may present pores to some extent.

- An external coating, similar to a covering skin or membrane, perfectly reproducing designs or relieves worked onto the basis steel surface.

- Very uniform thickness in cross sections, though found values may vary from $50-100$ micrometers. Nevertheless, a post depositional process of fluid accumulation beneath the surface, or in one or more cavities is likely

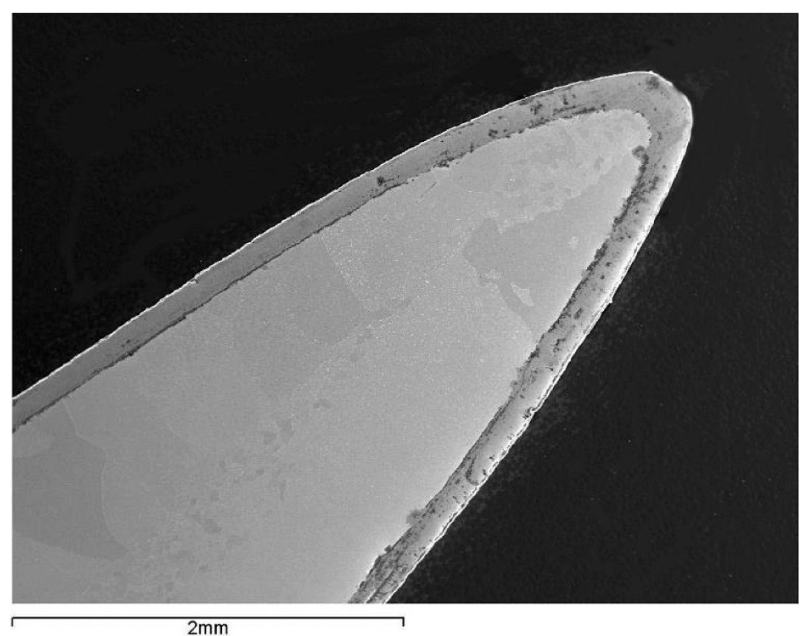

Figure 4. SEM image of the Iberian falcata. The sample belongs to the cutting edge close to the point, the continuous, homogeneous and compact magnetite layer can be seen.

Figura 4. Imagen SEM de la falcate ibérica. La muestra pertenece al filo cerca de la punta. Se aprecia la capa de magnetita continua, homogénea y compacta.

to take place, causing higher thickness. This in turn may cause descaling of the material.

- Its crystallographic microstructure is regular and uniform, developing a growth from the nucleus in radial or column shaped structural components.

- Shows good adherence, tenacity and thermal dilatation coefficients similar to those of iron (Pilling-Bedworth ratio between 1 and 2 value) figure 5 . During magnetite formation its volume is virtually equal to that of the substrate. This prevents fissures and detachment of the outer layer.

- A direct relation in between the degree of corrosion of the basis steel and the fracture and/or deformation of the outer magnetite layer (and the accumulation of external corrosion products) can be observed.

- The material is hard and tenacious, not easy to graze or to chafe and capable to support moderately intense impacts.

Unintentional magnetite formation during the cremation process could also been excluded, first because temperature and chemical conditions during the process do not favour the formation of a compact and homogeneous magnetite layer formation and second, because the conditions during cooling 

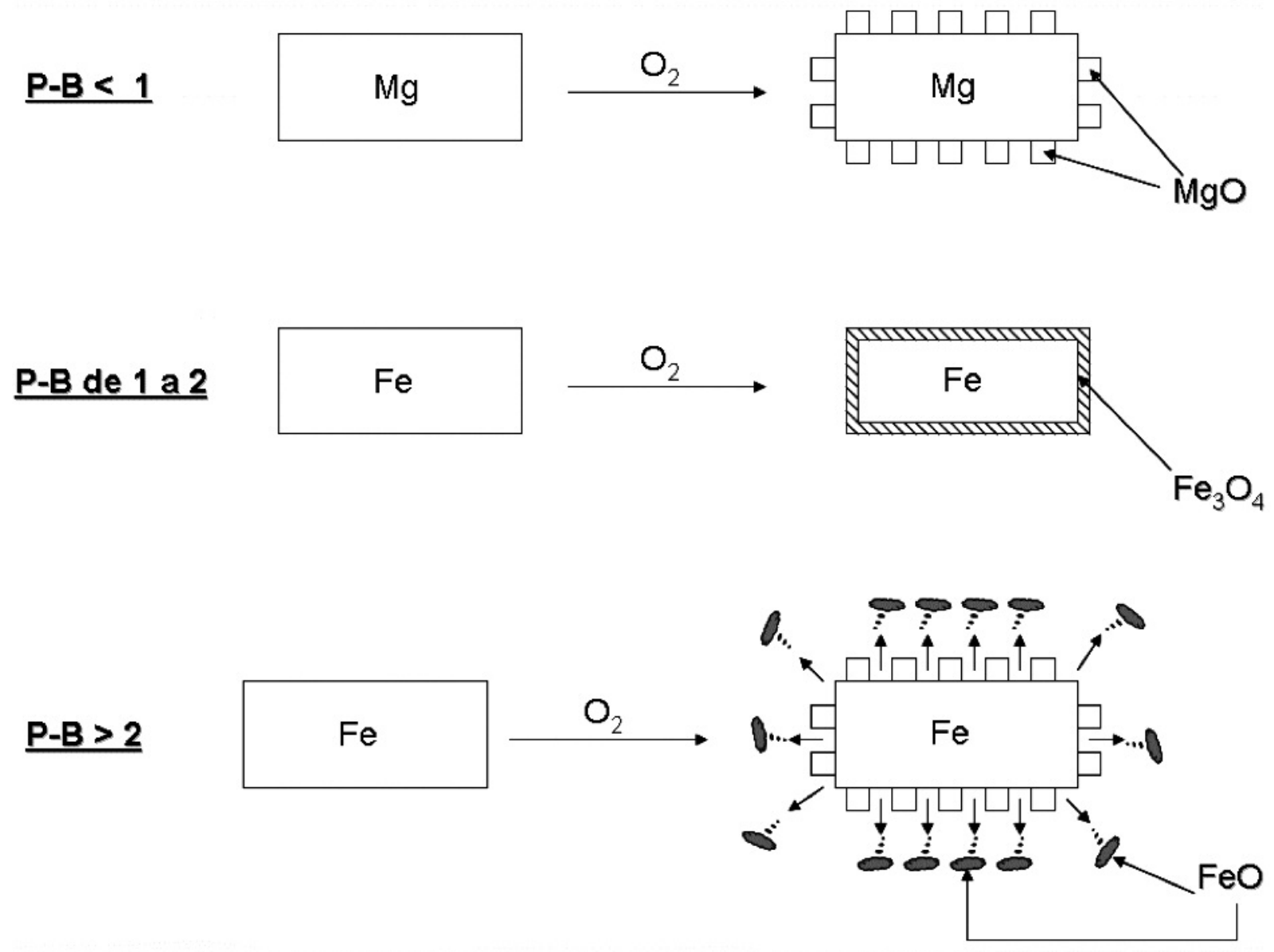

Figure 5. Scheme relating the formation of different oxides with its corrosion protector behaviour as the ratio Pilling-Bedworth classifies them.

\section{Figura 5. Esquema representando la formación de distintos tipos de óxidos y su carácter pro- tector de la corrosión según se clasifica con la relación Pilling-Bedworth.}

would have produced a quite different grain size distribution in the outer layer.

Assuming the before mentioned points, we believe that it is possible to establish a sequential typology of variations in topography by characterising morphostructural changes in the evolution surface. This in turn could provide a powerful tool in order to identify the presence of artificial magnetite layers, including at rather corroded metallic remains.

In spite of being rather continuous, homogeneous and compact, the magnetite layer possesses certain porosity, as can be seen in figure 6 a). Through these pores electrolytes may penetrate from the soil in which the burial was carried out, producing corrosion of the metallic nucleus underneath the protective layer ${ }^{[25}$ and 26$]$. This effect can be observed in figure 1A$6 \mathrm{~d}$ ), where the oxidation occurred over millennia, though not severe due to the protective properties of the magnetite layer, in some areas has produced corrosion which in turn caused detaching of the magnetite layer from the nucleus. Here, the tenacity of the artificial magnetite successfully prevented fracture of the layer in spite of suffering enhanced interstitial pressure caused by the higher volume of oxidation products. Nevertheless, a cremation process may cause partial or complete detachment of this layer.

The metallic nucleus of both pieces have, with slight differences, rather similar structures. They exhibit an idiomorphic needles of iron carbide structure type Widmanstätten, which is typical after cremation, though with higher quantity in the pilum than in the falcata (Figs. 7 y 8). Upper temperature limits achieved during a cremation process can be very high, reaching about $950-1000^{\circ} \mathrm{C}$, as proven by investigations on incinerated bones, melted bronze, etc. ${ }^{[27-32]}$ found in cremation burials. The structure type indicates that the cooling of the weapons occurred using severe temperature gradients, leaving at room temperature carbon saturated 

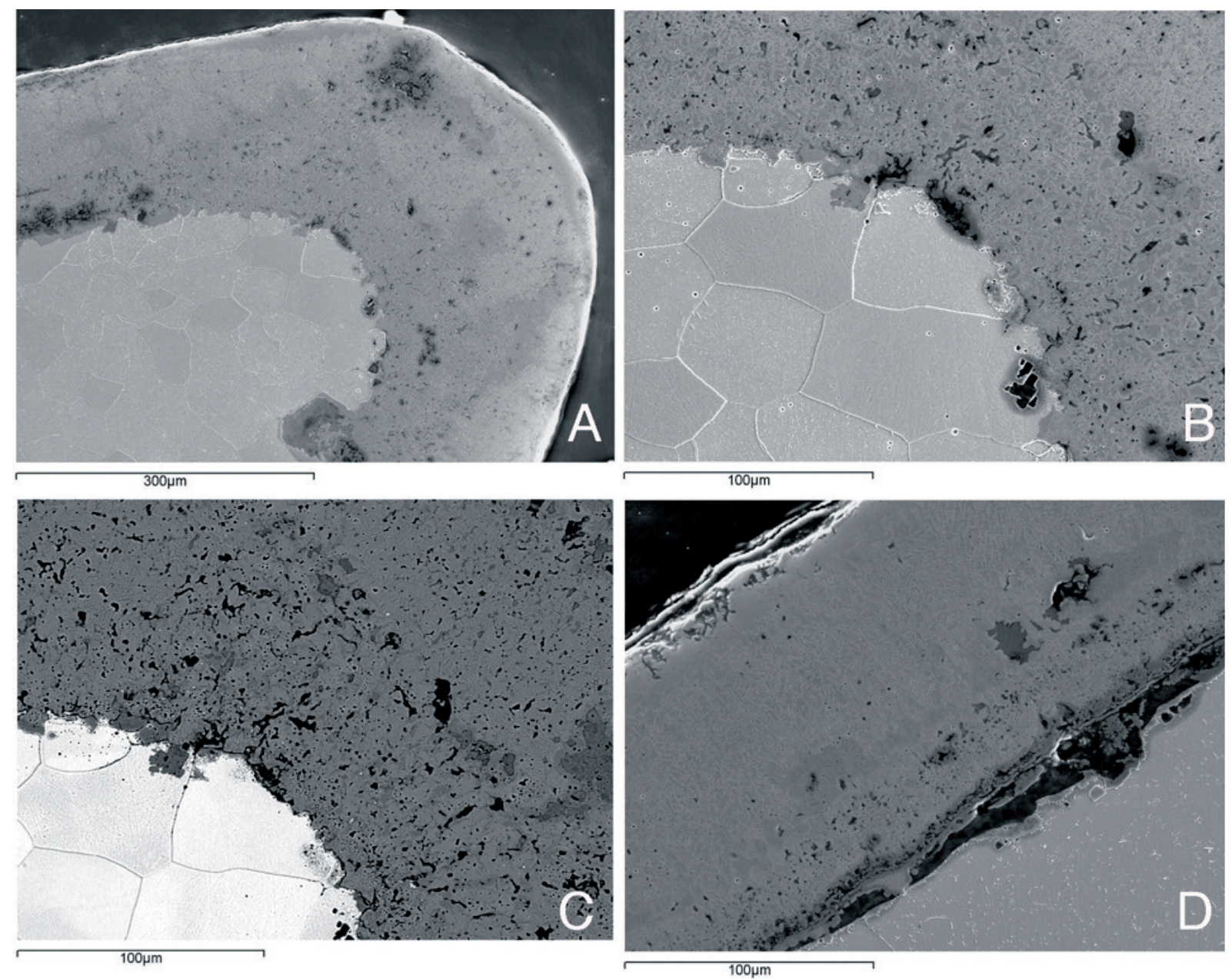

Figure 6. Detail from figure 4, the magnified zone is close to the cutting edge of the falcata (Fig. 6 a)); Further amplification of Fig. 6 a) showing the porosity of the magnetite in contact with the metallic zone of the edge (Fig. 6 b)); Identical to Fig. 6 b), but obtained in backscattered mode, which results in image contrast as a function of composition. Porosity of the magnetite layer can be clearly observed (Fig. 6 c)); SEM image of a zone which suffers detachment of the artificial magnetite layer from the metallic nucleus due to formation of corrosion products (iron oxides) (Fig. $6 \mathrm{~d}$ )).

Figura 6. Detalle de la figura 4, se muestra una zona cercana al filo de la falcate (Fig. 6 a)); Detalle aumentado de la Fig. 6 a) mostrando la porosidad de la magnetita que está en contacto con el núcleo metálico del filo Fig. (6 b)); La misma imagen que la Fig. 6 b) pero obtenida con electrones retrodispersados, lo cuales proporcionan un contraste en función de la composición. Se puede observar la porosidad de la capa de magnetita (Fig. 6 c)); Imagen MEB de la zona que ha sufrido un desprendimiento del recubrimiento de magnetita artificial debido a la formación de productos de corrosión (óxidos de hierro) entre el núcleo metálico y el recubrimiento (Fig. 6 d)).

quenched ferrite. The solubility of carbon in steel at ambient temperature is only $0.008 \%$ in weight, this fact provokes, over thousands of years, precipitation in these typical structures ${ }^{[33]}$. The nature of these precipitates was subject of discussion over the last decades, being the most accepted hypotheses an iron carbide or nitride. Some researches, e.g. Piaskowski and Broker et al postulated iron nitride compounds, due to either the nitrogen content of the proteins forming part of the incinerated body or to that the object has been heated in contact with combustion material containing ammonia, such as animal dung. In 1984, a team from Lehigh and Pennsylvania University ${ }^{[33]}$, making use of Transmission Electron Microscopy (TEM), established that in fact these precipitates are iron carbide. This 

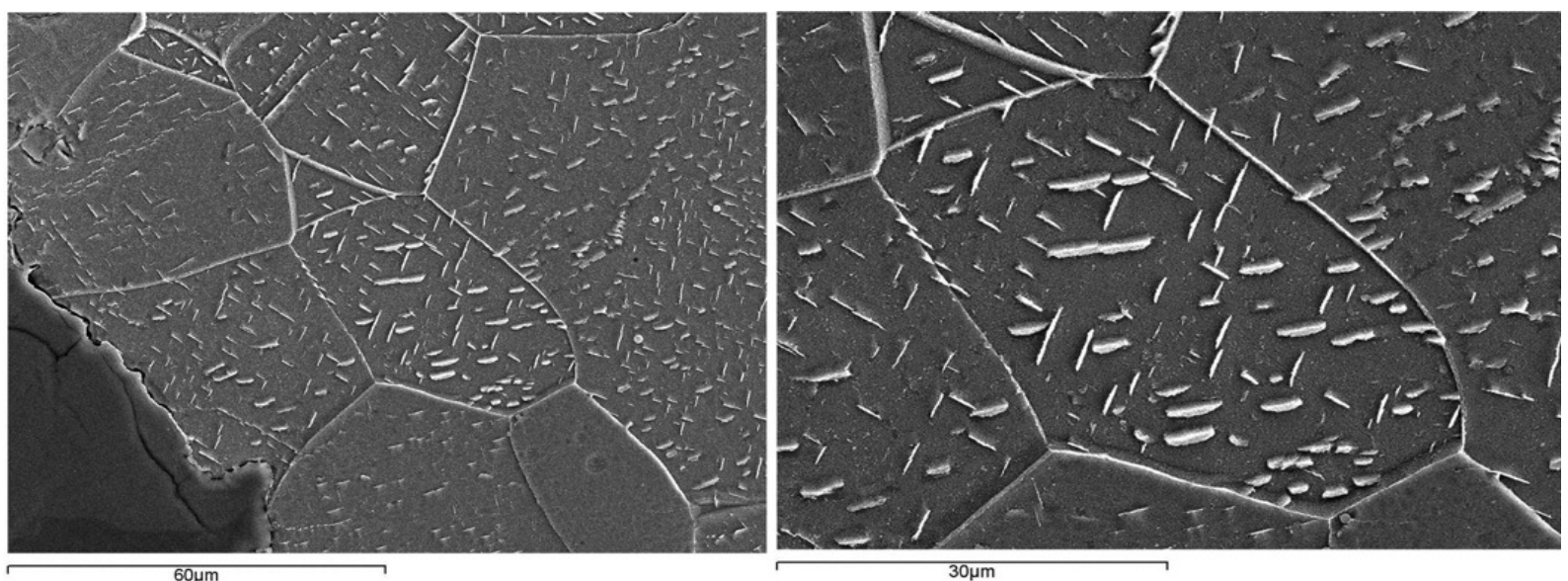

Figure 7. SEM image of the iberian pilum, a massive iron carbide precipitate in a ferrite grain matriz with Widmannstätten type structure can be seen ( 7 a left)); detail from Fig. 7 a); idiomorphic iron carbide morphology and presence of cementite at the ferrite grain boundaries can be distinguished (7 $\mathrm{b}$ right)).

Figura 7. Imagen MEB del pilum ibérico, se observa un precipitado masivo de carburos de hierro en la los granos ferríticos de la matriz. El precipitado muestra una estructura del tipo Widmannstätten (Fig. 7 a izquierda)); detalle de la Fig 7 a); Se puede distinguir la presencia de carburos de hierro ideomóficos y también presencia de cementita en los límite de grano ferríticos (7 b derecha)).
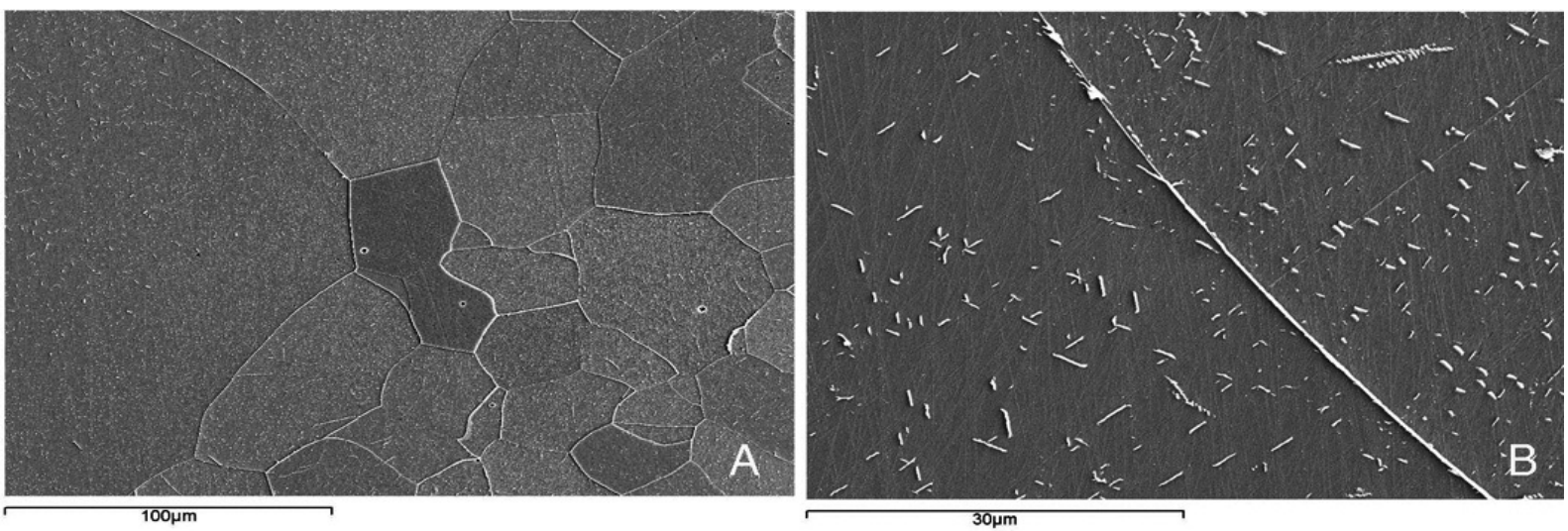

Figure 8. The structure of the metallic core of the falcata. A fine grained precipitate of iron carbide in a ferritic matrix of varying particle size is shown (Fig. 8 a)); detail from Fig. 8 a), idiomorphic iron carbide with Widmannstätten structure in the interior of ferrite grains are shown, as well as continuous cementite precipitation at the grain boundary (Fig. 8 b)).

Figura 8. Estructura del núcleo metálico de la falacata. Se aprecia un fino precipitado de carburos de hierro en la matriz ferrítica. Se observa una variación en el tamaño de partícula del precipitado (Fig. 8 a)); detalle de la Fig. 8 a). Se observan carburos de hierro idiomórficos con estructura Widmannstätten en el interior de los granos ferríticos, así como un precipitado de cementita continuo en el límite de grano (Fig. 8 b)).

finding is in-line with the results of EPMA analysis carried out within the present study (Fig. 9).

Another interesting fact which could be detected is related to the process of artificial magnetite formation, as mentioned above abundant in Iberian armoury, though only in the case of the metallic structure belonging to the falcate sample.

Observing the SEM images shown in figures 10 and 11 at low magnification, it can be clearly seen that the grain size of the ferrite crystals is much greater 


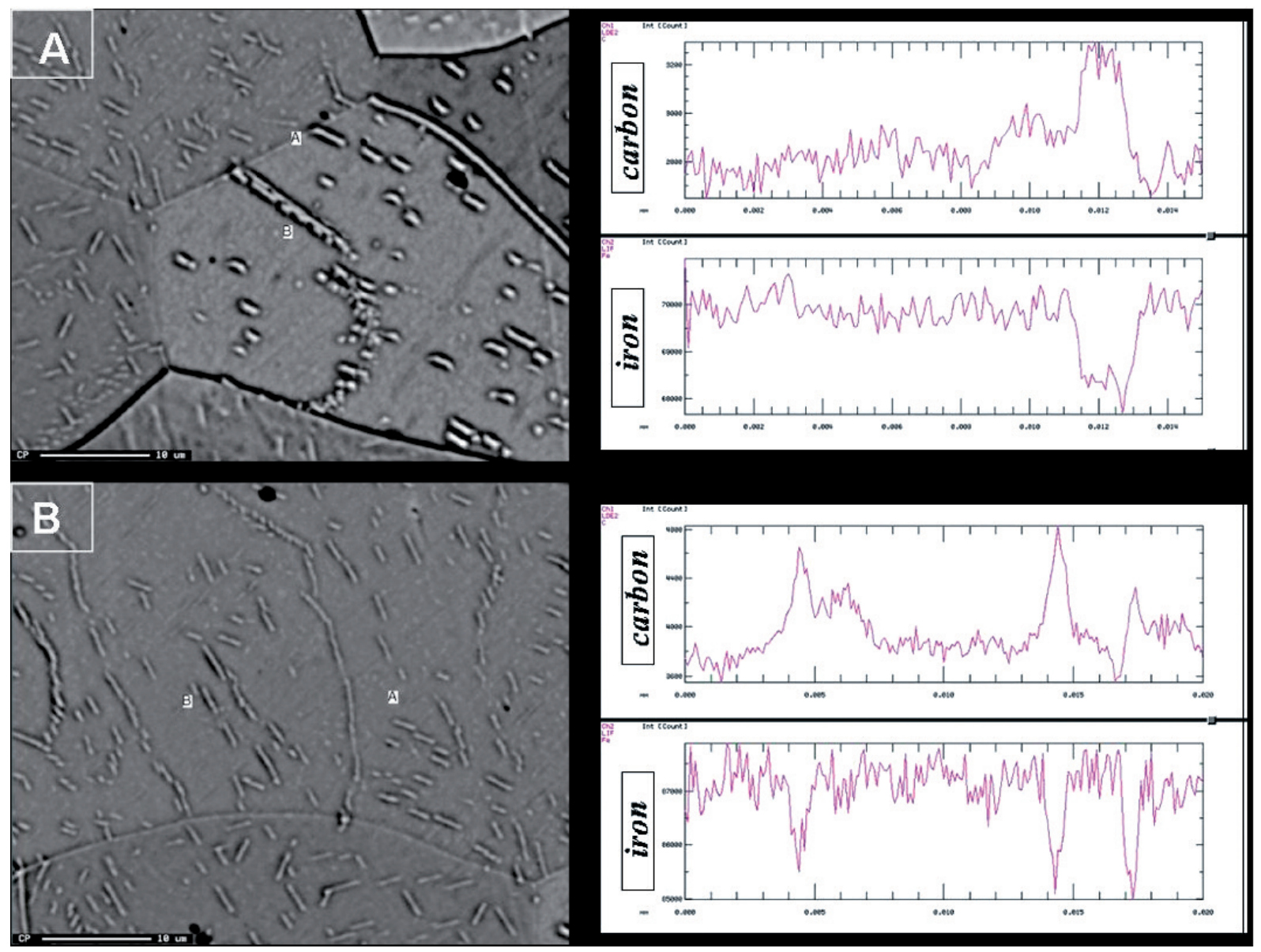

Figure 9. SEM images and corresponding results of EPMA. The fact that the analytical profile shows an increase of carbon combined with a decrease of iron when analyse the crystals with Widmannstätten structure indicates presence of iron carbide. The upper image corresponds to the pilum and the downer to the falcata.

Figura 9. Imágenes MEB correspondientes al resultado del EPMA. El hecho de que el perfil de análisis muestre un incremento de carbono combinado con un decrecimiento de hierro cuando se analizan los cristales con estructura Widmannstätten indica la presencia de carburo de hierro. La imagen superior corresponde al pilum y la inferior a la falcata.

at the outer than in the inner zone. The areas suffering more intense deformation after the process of hot forging of the blade were the external ones, which is generally happening in plastic deformation of steels and metals ${ }^{[34]}$. If a metal is exposed to elevated temperatures, recrystalisation accompanied by excessive grain growth occurs in those areas which are more intensively deformed. This is the case of the Iberian falcate, where recrystalisation and intense grain growth are due to heat exposure subsequent to the forging process, applying high temperatures and elevated time with the objective of obtaining a highly tenacious, temperature stable magnetite layer of appropriate thickness. In order to obtain a such protective and adherent layer, the work piece has to be covered with a fluxard based on refractory clay, thus preventing an excessive oxygen content which would bias the reaction towards $\mathrm{Fe}_{2} \mathrm{O}_{3}$ formation, a porous and less adherent material ${ }^{[35}$ and 36$]$.

As Criado, Juez-Lorenzo and Kolarik say in previous works not only oxidation of iron to its corresponding oxides takes place, but also reduction processes due to partial decarburation of the basis stee ${ }^{[36-39]}$. At high temperatures, the equilibrium between $\mathrm{Fe}_{2} \mathrm{O}_{3}$ and $\mathrm{Fe}_{3} \mathrm{O}_{4}$ within the $\mathrm{Fe}-\mathrm{FeO}-\mathrm{Fe}_{3} \mathrm{O}_{4}$ $\mathrm{Fe}_{2} \mathrm{O}_{3}$, system, is shifted towards the latter, due to reduction of $\mathrm{Fe}_{2} \mathrm{O}_{3}$ by means of $\mathrm{CO}$, which is forming when carbon dissolved in the basis steel diffuses to the surface during the decarburation process.

Results of experiments carried out in a temperature chamber X-ray diffractometer to understand the formation of oxides in steels ${ }^{[36-39]}$ can be summed up 


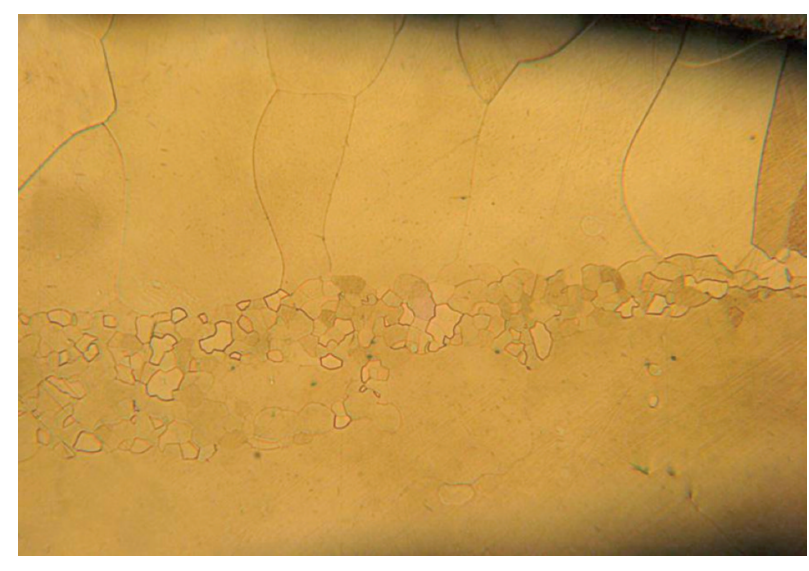

Figure 10. Image of a cross section of the falcata sample obtained by optical microscopy. The elevated grain size in the outer zone versus the small grains in the interior can be clearly distinguished.

Figura 10. Imagen de la sección de la muestra de la falcata en microscopio óptico. Se distingue el gran tamaño de los granos en la zona externa frente al tamaño de los granos en el interior.

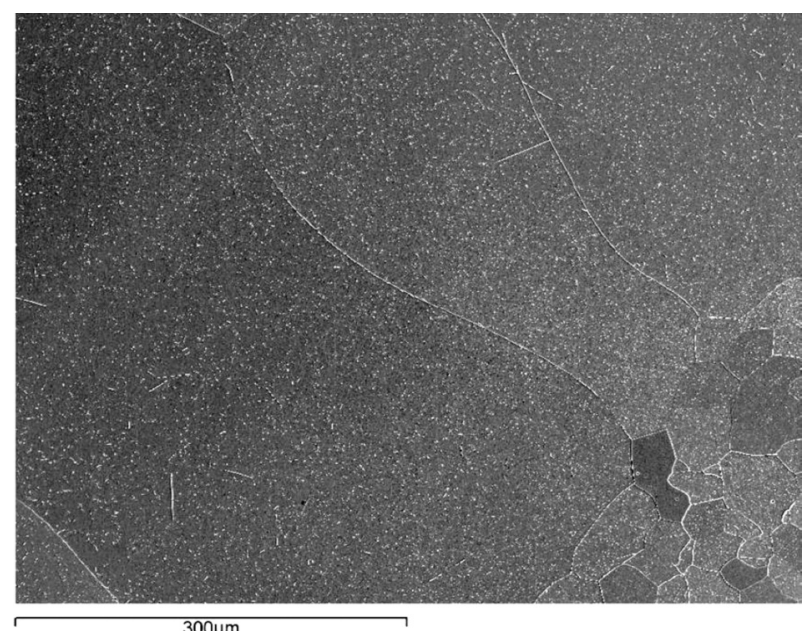

Figure 11. SEM image of the falcata sample. The elevated grain size in the outer zone versus the small grains in the interior can be clearly distinguished.

Figura 11. Imagen MEB de la muestra de la falcata. Se distingue el gran tamaño de granos en la zona externa frente al tamaño de grano internos.

in these terms: Low oxygen pressures enhance the formation of $\mathrm{Fe}_{3} \mathrm{O}_{4}$ and prevent the formation of $\mathrm{Fe}_{2} \mathrm{O}_{3}$. At normal oxygen condition, does not start the formation of $\mathrm{Fe}_{2} \mathrm{O}_{3}$ during the evolution of $\mathrm{Fe}_{3} \mathrm{O}_{4}$ since $570{ }^{\circ} \mathrm{C}$ but only appears in minimal quantities. It is only from $800{ }^{\circ} \mathrm{C}$ when $\mathrm{Fe}_{2} \mathrm{O}_{3}$ when starts its formation in significative manner.

The analysis of archaeological samples detect magnetite, as well as in the laboratory simulation using boronoxide as a fluxard, therefore it is presumable that a sort of clay was used to prevent the massive diffusivity of oxygen when the magnetite coating was manufactured in the archaeological objects.

Nearly exclusive magnetite formation in the simulation was obtained at retention times between 15 and $30 \mathrm{~min}$, exceeding this period, growth of a $\mathrm{Fe}_{2} \mathrm{O}_{3}$ occurred. Optimum conditions for magnetite formation were found to be a temperature of 950 ${ }^{\circ} \mathrm{C}$ and a retention time of $15 \mathrm{~min}$. After polishing, the outer layer presented a matt black colour with metallic lustre. Once cooled down, its adherence to the basis steel was strong enough to sustain moderate strokes with a forging hammer.

As shown in figure 12, highly adherent and tenacious magnetite layers of different thicknesses were obtained. Magnetite possesses a dilatation coefficient similar to that of iron, this facilitates good adherence properties. In spite of having suffered a cremation, the magnetite layer of the falcata is basically intact and has lost adherence only in a small

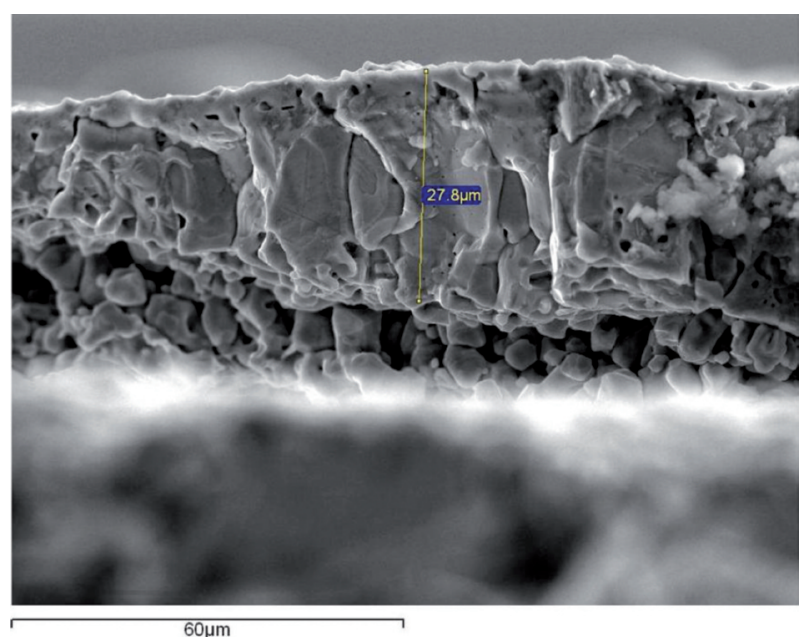

Figure 12. SEM image of the artificially created magnetite layer. The furnace was operated under oxidising atmosphere over 10 min applying boron oxide as fluxard.

Figura 12. Imagen MEB de la capa de magnetita artificial reproducida hoy día. El horno se utilizó en condiciones oxidantes normales durante 10 min aproximadamente. Se utilizó óxido de boro como fundente. 
proportion, the latter most possibly not by impact of heat but by subsequent corrosion processes during the 2.000 years the artefact was buried.

When observing the falcate sample the decarburation of the surface suffered is clearly shown. It is distinguish because appears different quantities of iron carbide between the core and the external zone. This is due to the gradual diffusion of the process.

\section{CONCLUSIONS}

- Macroscopic observation of the artefacts determines that both falcata and pilum, were covered by an artificial magnetite layer.

- This finding suggests the hypothesis that the majority of similar pre-roman Iberian weapons may have been treated in the same manner, producing a protective superficial layer. Cases in which the presence of this layer could not be confirmed may be due to that their degree of conservation was not adequate or that remains of the layer were removed during previous restoration campaigns, when the presence of an intentional magnetite layer was still not under study. This hypothesis will need further research and systematic study of more Iberian armours to be confirmed.

- The recrystalisation behaviour of the falcata suggests that the artificial magnetite layer has been formed by heating at high temperatures, applying a fluxard based on refractory clay in order to control oxygen uptake and to assure a tenacious and thoroughly attached magnetite layer upon the metallic substrate. Both samples show needle-like precipitations of iron carbide with Widmanstätten structure inside ferritic grains, typical for steel specimen exposed to cremation processes. EPMA analysis furthermore supports the theory that the nature of these precipitates is iron carbide instead of iron nitride.

- Natural corrosion did not significantly affect the areas of the arms where the magnetite layer kept more or less intact after the cremation. The pilum is in worse conditions of conservation due to the fact that this layer remained only in a zone close to the tip of the, meanwhile over the rest of the artefact the layer detached during cremation.

- Future investigation will be focussed on trying to clarify whether this technique can be classified as genuine Iberian or whether it was adopted by preroman tribes in contact with the Celts. Ongoing studies are as well centred on a more detailed investigation of the magnetite production process itself, e.g. which clays were originally used as fluxard and at which temperatures. In this context areas in the Spanish Peninsula where this technique is still in use will be studied. As example, Sierra Morena in Andalusia may be mentioned, where herdsmen still fabricate bells for cattle and goats in that manner.

\section{Acknowledgements}

The authors want to thank to Alfonso Rodríguez and Alfredo Fernández, from the Centre for Electron Microscopy "Luis Bru" of the Complutense University for providing help and advice concerning SEM/EDX and EPMA data.

\section{REFERENCES}

[1] M.B. Deamos y T. Chapa Brunet, La Edad del Hierro, Ed. Síntesis, S.A. Madrid, España, 1997, pp. 153-182.

[2] M. Almagro, O. Arteaga, M. Blech, D. Ruíz Mata y M. Schubart, Chapter 5: Segunda edad del hierro, in Protohistoria de la Península Ibérica, Ed. Ariel, S.A., Barcelona, España, 2001, pp. 329-357.

[3] F. Quesada Sanz, Arma y símbolo: La Falcata Ibérica, Ed. Instituto de Cultura Juan GilAlbert, Alicante, España, 1992, pp. 43-87.

[4] A.J. Lorrio Alvarado, S. Rovira Llorens y F. Gago Blanco, Lucentum. XVII-XVIII, (1998/1999) 149-161.

[5] J.M. García Cano y M. Gómez Ródenas, Gladius 26 (2006) 61-92.

[6] Polibio, Historia de Roma (III 114, 2-4), Ed. Alianza, Madrid, 2008, pp.58-60.

[7] Polibio, Historia de Roma (VI, 23), Ed. Alianza, Madrid, 2008, pp.120.

[8] Diodoro de Sicilia, Biblioteca Histórica (V 33, 2-5), Ed. Gredos, Madrid, 2008, pp. 57-60.

[9] Aulo Gelio, Noches Áticas (II, IX, XIII, 9-17), Ed. Akal/Clásica, Madrid, 2009, pp. 17,48,104.

[10] Tito Livio, Historia de Roma (XXI, 5,5) Ed. Alianza, Madrid, 1992, pp. 223.

[11] L.A. Floro, Compendio de la Historia de Roma (II, 7-9), Ed. Gredos, Madrid, 2000, pp. 78-79.

[12] A.J. Criado, W. Engel, N. Eisenreich, V. Kolarik y M. Juez-Lorenzo, J. Phys. III, (1992) 357-362.

[13] R. Dieckmann, Berichte der Bunsen - Gesellschaft fur Physikalische Chemie 86 (1982) 112-118.

[14] R. Dieckmann, Relationships Between Defect Structure, Transport Properties and the Growth 
Rate of Dense Magnetite Scales During Simple Reactions in the System Iron-Oxygen, in: High Temperature Corrosion, Ed. R.A. Rapp, Houston, Texas, 1983, pp. 70-75.

[15] R. Dieckmann y H. Schmalzried, Berichte der Bunsen-Gesellschaft fur Physikalische Chemie 81 (1977) 344-347.

[16] R. Dieckmann y H. Schmalzried, Berichte der Bunsen-Gesellschaft fur Physikalische Chemie 81, (1977) 414-419.

[17] M. Juez-Lorenzo, V. Kolarik, N. Eisenreich, W. Engel y A.J. Criado, Proceedings of the Second European Powder Diffraction Conference, 1992, Vol. 2, R. Delhez, E.J. Mittemeijer (Eds.) Aedermannsdorf Trans Tech Publications, Enschede, The Netherlands, 1993, pp. 560-574.

[18] M. Juez-Lorenzo, V. Kolarik, N. Eisenreich, W. Engel y A.J. Criado, J. Phys. IV, (1993) 461-467.

[19] H.H. Coghlan, Sibrium 3 (1956-57) 167-174.

[20] J. Alonso, Actas de Metalespaña Madrid, España, 2008, J. Barrio y E. Cano (Eds.) UAM, Madrid, España, 2009, pp.134-142.

[21] A. Madroñero de la Cal, Kalathos (1983-1984) pp. 139-148.

[22] H. SANDARS, The Weapons of the Iberians. Archaeologia or Miscellaneous tracts relating to Antiquity, segunda serie, volumen XIV Ed. Facsímil, Oxford, England, 1913, pp. 205-294.

[23] E. Cabré de Morán y M.I. Baquedano Beltrán, La Guerra en la Antigüedad, una aproximación a origen de los ejercitos en Hispania, Ed. Fundación Caja Madrid, Ministerio de Defensa, Madrid, 1997, pp. 240-259.

[24] J. Alonso, I. Filloy y R. Cerdán, Nuevas técnicas metalúrgicas en armas de la II Edad del Hierro, Ed. Foru-Aldundía, Diputación Foral de Álava, España, 1999, pp. 124-131.

[25] A.J. Criado, A. Martínez, R. Calabrés, A. García, F. Penco y J.A. Lecanda, Análogos Arqueológicos e industriales para almacenamientos profundos: estudio de piezas arqueológicas metálicas, Archeo I. ENRESA, Publicación Técnica 00/07, Madrid, España, 2000, pp. 1-204.
[26] A.J. Criado, J.A. Martínez García y E. Bravo Muñoz, Análogos arqueológicos e industriales para almacenamientos profundos: estudio de piezas arqueológicas metálicas. Archeo II. ENRESA, Publicación Técnica 03/03, Madrid, España, 2003, pp. 1-276.

[27] S. Enzo, M. Bazzoni, V. Mazzarello, G. Piga, P. Bandiera y P. Melis, J. Archaeol. SCI 37 (2007) 1731-1737.

[28] C. Wells 1960, Antiquity 34 (1960) 29-37.

[29] J.L. McKinley, Proceedings of the Prehistoric Society 63, Prehistoric Society, Royaume-Uni, London, England, 1997, pp. 129-145.

[30] S. Hummel, H. Schutkowski y B, Herrmann, Actes des 3ieme Journees Anthropologiques, Note et Monographies Techniques 24 Valbonne, CNRS, Ed. Paris, Francia, 1988, pp. 177-194.

[31] J, Piaskowski, J. Iron Steel Res. Int. 198 (1961) 263-282.

[32] G.R. Booker, J. Norbury y A.L. Sutton, J. Iron Steel Res. Int. 187 (1957) 205-215.

[33] K.H. Liu, H. Chan, M.R. Notis y V.C. Pigott, Microbeam Analysis, A.D. Romig Jr. y J.I. Goldstein (Eds.), San Francisco Press, San Francisco, EE.UU., 1984, pp. 261-263.

[34] G.E. Dieter, Jr., Mechanical Metallurgy, SI metric edition, McGraw-Hill Book Co., New York, EEUU, 1988, pp. 503-563.

[35] F.R. Morral, E. Jimeno y P. Molera, Metalurgia General Tomo II, Ed. Reverté S.A., Barcelona, España, 1985, pp. 1008-1011.

[36] H.A. Wriedt, Binary Alloy Phase Diagrams, ASM International, 2nd edition, Materials Park, $\mathrm{OH}$, EE.UU., 1990, pp. 846-849.

[37] M. Juez-Lorenzo, V. Kolarik, N. Eisenreich, W. Engel y A.J. Criado, J. Phys. IV (1992) 351-357.

[38] M. Juez-Lorenzo, Tesis Doctoral, Facultad de Ciencias Químicas, Universidad Complutense de Madrid, 1993.

[39] V. Kolarik, Doktors der Naturwissenschuften. Hüttenwesen und Geowissenschaften der Rheinisch-Westfälischen Technischen Hochschule Aachen, 1993. 